\title{
LOW-TEMPERATURE AND TEMPERATURE STEPPED-COMBUSTION OF TERRACE SEDIMENTS FROM NANFU, TAIWAN
}

\author{
Shing-Lin Wang ${ }^{1,2} \bullet$ George S Burr ${ }^{1,3} \bullet$ Yue-Gau Chen ${ }^{1}$ Yin Lin $^{1} \bullet$ Tzu-Shuan Wu ${ }^{1}$ \\ ABSTRACT. We discuss a radiocarbon study of sediment samples collected from Nanfu terrace in western Taiwan. From \\ these, we extracted humic acids (HA) and humin from the very fine and coarse grain-size fractions using a standard acid- \\ alkali-acid pretreatment. The humin extracts were combusted at 400 and $1100^{\circ} \mathrm{C}$ by stepped-combustion, to yield a low-tem- \\ perature (LT) carbon component and a high-temperature (HT) carbon component. We compare the ages of the LT and HT \\ humin fractions to the HA fractions, in samples collected at 2 depths within the Nanfu terrace. As in previous stepped-com- \\ bustion studies on sediments, we find that the HA ages are the youngest on average, and overlap the LT ages, and that the car- \\ bon contained in the HT fraction is always distinctly older than the LT and HA ages. To better understand the relationship \\ between ${ }^{14} \mathrm{C}$ age and combustion temperature, we conducted an incremental stepped-combustion experiment with one of the \\ samples (1E) using $50{ }^{\circ} \mathrm{C}$ steps that ranged from 300 to $1100^{\circ} \mathrm{C}$. The ${ }^{14} \mathrm{C}$ results of the stepped-combustion products show a \\ clear division between 2 isotopically identifiable carbon constituents, from carbon released below $400{ }^{\circ} \mathrm{C}$ and carbon released \\ above $550{ }^{\circ} \mathrm{C}$. By comparing the $\delta^{13} \mathrm{C}$ and ${ }^{14} \mathrm{C}$ results, we find evidence for a third carbon isotopic component in the humin \\ that is released when combusted at $\sim 500{ }^{\circ} \mathrm{C}$.
}

\section{INTRODUCTION}

The tectonics of western Taiwan are dominated by the collision of the Philippine Sea Plate and the Eurasian continental margin, while the tectonics of northeastern Taiwan are subject to crustal extension within the Ryukyu-Okinawa back-arc region (Shyu et al. 2005). Successive levels of fluvial terraces are well developed along most of the rivers in western Taiwan and these reflect the active tectonic setting and high uplift rates characteristic of the region. Historically, obtaining age control of the terraces has been difficult for a variety of reasons. Optically stimulated luminescence (OSL) dates may be affected by partial bleaching of the luminescence signal due to rapid and sporadic fluvial sediment transport. Erosion of old deposits from the Taiwan Central Range can result in incompletely zeroed sediments, and overestimated OSL ages that imply unreasonably low uplift rates (Ota et al. 2009). Traditional radiocarbon dating is limited by the sparse organic remains typically found in fluvial sediments in Taiwan.

Since charcoal, wood or macrofossils are difficult to find, bulk sediments have been used for dating. However, organic carbon contained in bulk sediments is often heterogeneous with respect to ${ }^{14} \mathrm{C}$, and in general, ${ }^{14} \mathrm{C}$ ages from bulk sediments can only provide broad chronological control for sediment deposition in Taiwan. Still, in the absence of other datable carbon, bulk sediment at least has the potential to place constraints with known errors on the age of a sediment layer. On fluvial terraces, the sources of organic carbon in sediments are derived from the ongoing decomposition of plant debris in the topsoil as well as detrital carbon introduced during floods. Such dates may be used to determine an integral age for a buried soil, representing the time that they were actively fixing carbon from the surface. In the typically warm and wet environments of Taiwan, soil development occurs relatively rapidly, and the faster the soil forms, the better the potential age resolution using ${ }^{14} \mathrm{C}$ dating. The goal of the work described here is to use the stepped-combustion approach in an attempt to identify particular organic components that, contribute to the ${ }^{14} \mathrm{C}$ heterogeneity of bulk sediments from the chosen site. Ultimately, we hope to identify components that can be used to

\footnotetext{
${ }^{1}$ Department of Geosciences, National Taiwan University, Taiwan.

${ }^{2}$ Corresponding author. Email: jslwang@ntu.edu.tw.

${ }^{3}$ NSF-Arizona AMS Laboratory, Department of Physics, University of Arizona, Tucson, Arizona, USA.
} 


\section{S-L Wang et al.}

refine sediment ages across Taiwan, to assist in our understanding of the nature of climate change through time, as well as rates of neotectonic movements.

Humic acids (base-insoluble) and humin (base- and acid-insoluble residues, see below) are often used for ${ }^{14} \mathrm{C}$ dating sediment samples, but humic acids are sometimes younger than humin, and vice versa, depending on the site (Martin and Johnson 1995; Xu et al. 2004). This inconsistency occurs because humic acids and humin are themselves a mixture of organic compounds. Humin extracted from sediments contains a mixture of organo-mineral complexes that are bound to clay minerals. The residence time of organic carbon in soil or sediment depends on biomolecules, and the manner in which these are attached to mineral surfaces (Sutton and Sposito 2005). It has been shown that the amount of organic carbon is proportional to the clay mineral content in sediment (Torn et al. 1997; Six et al. 2002). Moreover, the organic carbon associated with clay can survive biodegradation in soil or sediment for several millennia (Anderson and Paul 1984; Eusterhues et al. 2003; WattelKoekkoek et al. 2003). Sutton and Sposito (2005) also mention that chemically extracting specific compounds are likely to change the properties of the humic substances themselves. Therefore, it is desirable to separate organo-mineral complexes from bulk sediments via a physical method in order to determine their ${ }^{14} \mathrm{C}$ ages. Density or size fractionations have long been used to isolate organic carbon from soil (Trumbore et al. 1996; Balesdent et al. 1998). Whereas these 2 methods successfully isolate modern carbon from older carbon groups of organo-mineral complexes in soil, they cannot effectively separate stabilized organic carbon of different ages (Schöning et al. 2005, Schöning and Kögel-Knabner 2006; Sollins et al. 2006).

This study evaluates the combustion technique of McGeehin et al. (2001, 2004) and extends the approach with an incremental stepped-combustion experiment. Previous studies have repeatedly shown that based on ${ }^{14} \mathrm{C}$ there are several ${ }^{14} \mathrm{C}$ components in the humic acid and humin fraction of sediments sieved to $<64 \mu \mathrm{m}$ and low temperature can separate out one of them (McGeehin et al. 2001, 2004). The same result has been reported for carbon in clay minerals (Burr et al. 2009). The above results show that sieving combined with stepped-combustion can be used to separate and quantify ${ }^{14} \mathrm{C}$ ages of individual carbon pools that are mixed together in the fine fraction of sediments (silt and clay). This study was undertaken to find out at exactly what temperatures these components were liberated through combustion, to optimize the separation among them. Taken together, this information can bracket the age of a sediment and help to identify pathways of organic carbon into the terrace soils of western Taiwan.

\section{SAMPLE LOCATION AND METHODS}

Nanfu terrace is located in the middle reach of the Chungkang River in northwestern Taiwan (Figure 1a). Compared with other parts of Taiwan, tectonic deformation and associated seismic activity in the northwest are more subdued (Yu et al. 1997; Shyu et al. 2005). A gentle, regional uplift is likely produced by the activity of a regional detachment underneath this area (Suppe and Namson 1979). Two proposed active faults traverse the Chungkang River. The Shitan Fault, in the upper reach of the river, ruptured during a M7.1 earthquake in 1935. The Touhuanping Fault, in the lower reach, apparently ruptured at least twice during the past $80 \mathrm{kyr}$ (Ota et al. 2009). However, the middle reach of the river, where the Nanfu terrace is located, does not seem to be affected by any active deformation. Thus, we believe that soil development on this terrace reflects relatively recent climate in northwestern Taiwan.

The elevation of Nanfu terrace ranges from 120 to $135 \mathrm{~m}$ above sea level, 10 to $25 \mathrm{~m}$ above the riverbed, and belongs to the lowest terrace level along the river. In a riverbank cut, fluvial gravels 
(a)

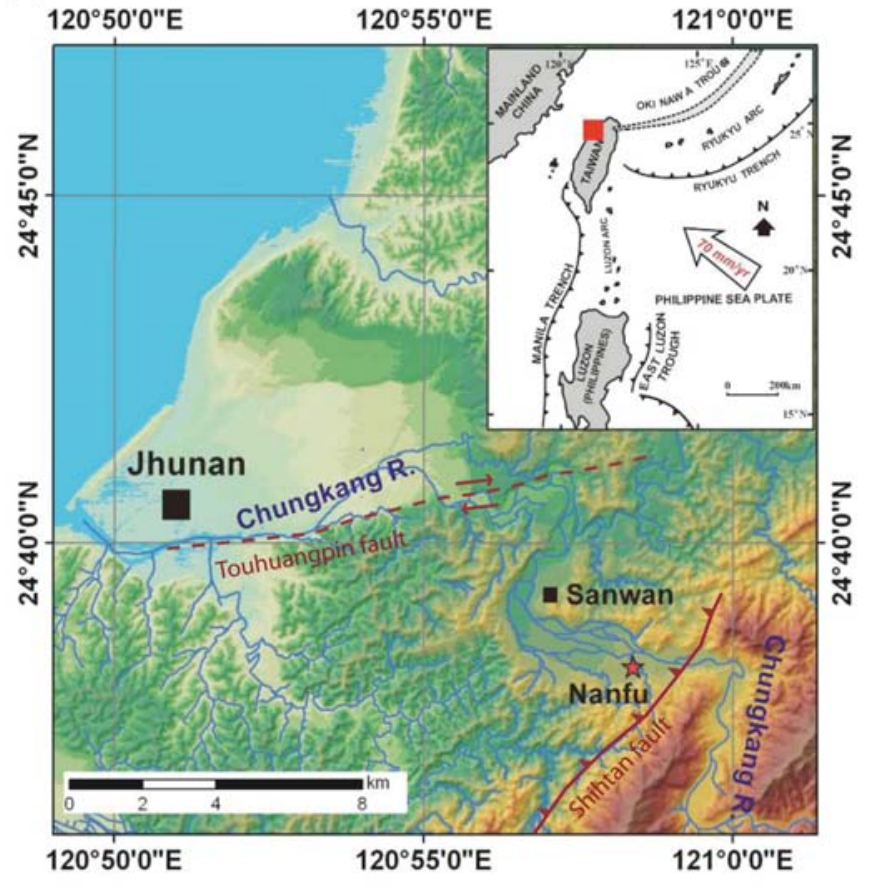

(e)

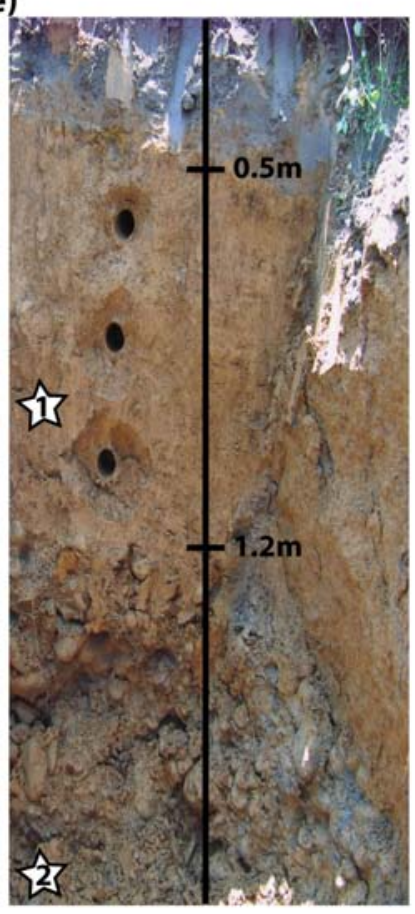

\section{(b)}

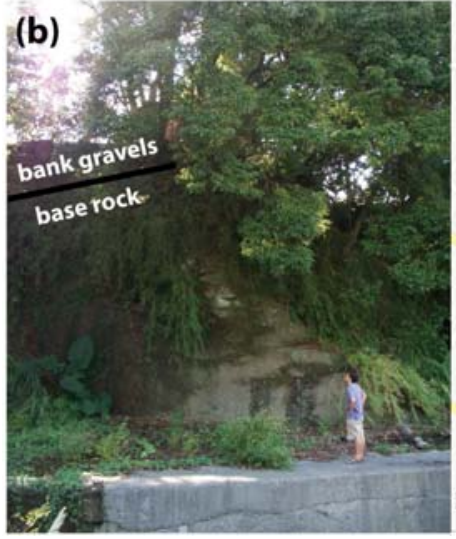

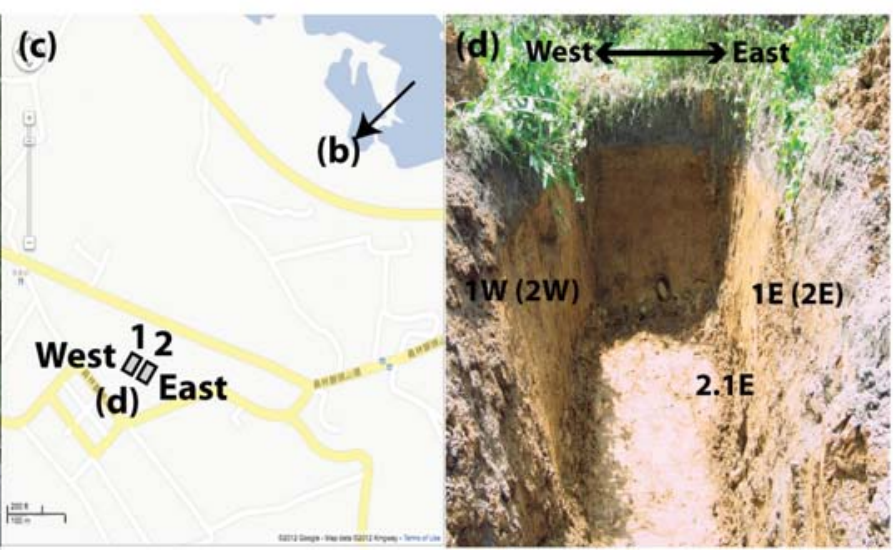

Figure 1 (a) Nanfu terrace is located along the middle course of the Chungkang River, northwestern Taiwan. (b) The cut of riverbank shows exposed bedrock and an upper layer of fluvial gravels. (c) (modified from Google ${ }^{\circledR}$ map) Location of 2 trenches on Nanfu terrace are marked as 2 rectangular boxes, and sample identification is denoted as trench 1, 2 and west side (W) and east side (E) accordingly. (d) The vertical location of samples collected in 2 trenches. (e) The depth of the trench is about $2.2 \mathrm{~m}$ and the profile includes $0.5 \mathrm{~m}$ topsoil, $0.7 \mathrm{~m}$ underlying sand, and a cobble layer at the bottom. Level 1 (star 1) samples are collected at $1 \mathrm{~m}$ below surface and level 2 (star 2) samples are collected $1 \mathrm{~m}$ below level 1.

are observed about $8 \mathrm{~m}$ above the riverbed and underlying bedrock is exposed (Figure 1b, arrow in Figure 1c). From all indications of our field study, this thick layer of fluvial gravels appears to cover the entire Nanfu terrace. Optically stimulated luminescence (OSL) data of samples collected at the boundary of bedrock and fluvial gravels in related sites suggest that the terrace formed more than 20 kyr cal BP (Chen 2006). This gives us a maximum age for the formation of the Nanfu terrace. In 


\section{S-L Wang et al.}

this study, we collected samples at the boundary of the thick fluvial gravels, and within the upper sand/silt layer, to constrain the age of carbon fixation in these sediments.

Sediment samples were collected from 2 trenches that were excavated in the middle of a rice field. The site was selected to avoid any human impacts on the terrace. The orientation of the 2 trenches was roughly north-south (Figure 1c), and samples were collected from both the east (E) and west (W) sides of 2 trenches. The samples are identified as 1E, 1W, 2E, and 2W (map in Figure 1c and trenches in Figure 1d). The depositional profiles from both trenches show the same stratigraphic features with a $0.5-\mathrm{m}$ black cultivated soil layer on top, a $0.7-\mathrm{m}$ brown sand/silt layer beneath this, and a distinct cobble layer beneath the sand and silt layer (Figure 1e). These features are typical of fluvial deposits in Taiwan. Level 1 includes 4 samples (1E, 1W, 2E, and 2W) collected from the matrix of the sand/silt layer, approximately $1 \mathrm{~m}$ below the surface. One sample (2.1E) was collected $1 \mathrm{~m}$ below sample 2E, well inside the cobble layer (Figure 1e).

All of the above sediment samples were sieved to $<64 \mu \mathrm{m}$ and $150-1410 \mu \mathrm{m}$, to isolate silt- and clay-sized material and coarser grains. These are referred to below as the fine and coarse fractions, respectively. All fractions of different sizes were then subjected to an acid-alkali-acid (AAA) pretreatment. The HA fraction was precipitated from the alkali-soluble eluant of the AAA pretreatment, and humin (insoluble residue) was collected at the end of the pretreatment. All samples were combusted, converted to graphite, and analyzed at the NSF-Arizona AMS facility in Tucson, Arizona, USA. One sample, $1 \mathrm{E}$, was combusted at $50{ }^{\circ} \mathrm{C}$ increments from 300 to $800{ }^{\circ} \mathrm{C}$, and the remainder (>800 ${ }^{\circ} \mathrm{C}$ fraction) was combusted at $1100{ }^{\circ} \mathrm{C} .{ }^{14} \mathrm{C}$ ages and $\delta^{13} \mathrm{C}$ measurements were made on each step, except for cases where an insufficient amount of $\mathrm{CO}_{2}$ was produced. ${ }^{14} \mathrm{C}$ ages of all samples, except stepped-combustion fractions, were calibrated to calendar years using the CALIB v 6.10 program (Stuiver et al. 2005) (Table 1).

\section{RESULTS}

We performed an incremental stepped-combustion experiment for the fine fraction $(<64 \mu \mathrm{m})$ from Nanfu sample 1E (Table 1, Figure 2). Figure 2a shows data from 300 to $1100{ }^{\circ} \mathrm{C}$, with associated ${ }^{14} \mathrm{C}$ ages and the percent total carbon extracted for each temperature step. We observe that more than half of the carbon is contained in the $<400{ }^{\circ} \mathrm{C}$ humin fraction, and that only a small fraction is recovered above $>550^{\circ} \mathrm{C}$. At these high temperatures, this carbon must be bound in mineral lattices and has the oldest ${ }^{14} \mathrm{C}$ age, as expected. From the ${ }^{14} \mathrm{C}$ results, we can immediately identify 2 end-member carbon components with distinct ${ }^{14} \mathrm{C}$ ages: 1 ) a $<350$ to $400{ }^{\circ} \mathrm{C}$ fraction and 2) a $>550{ }^{\circ} \mathrm{C}$ fraction. In Figure 2a, intermediate values appear to be a mixture of these $2{ }^{14} \mathrm{C}$ sources. However, when we also plot the $\delta^{13} \mathrm{C}$ results against fraction modern carbon (F) (Figure 2b), we find a third component, which is most obvious in the $500{ }^{\circ} \mathrm{C}$ fraction. In Figure $2 \mathrm{~b}$, the low-temperature end-member $\left(\sim 300^{\circ} \mathrm{C}\right)$ and high-temperature end-member $\left(\sim 1100{ }^{\circ} \mathrm{C}\right)$ have similar $\delta^{13} \mathrm{C}$ values but different $\mathrm{F}$ values. In addition, an intermediate temperature end-member $\left(\sim 500{ }^{\circ} \mathrm{C}\right)$ has a more negative $\delta^{13} \mathrm{C}$ value and its $\mathrm{F}$ value falls between the previous 2 end-members.

In Figure 3 and Figure 4, we plot all of the results for the samples, from both level 1 and level 2. Figure 3 shows calibrated ages. Results from the coarse fraction $(150-1410 \mu \mathrm{m})$ are given the suffix "C" and the results from the fine fraction have no suffix. We can make several observations from Figure 3: 1) the HA ages from all of the samples, at both levels, fall between 2000 and $4000 \mathrm{cal} \mathrm{yr}$ $\mathrm{BP}$ with no clear stratigraphic division; 2) the LT humin ages range from 3000 to $6000 \mathrm{cal} \mathrm{BP}$, and as with the HA ages, there is no clear division between the ages of level 1 and 2; 3) the oldest ages observed for all the samples are from the coarse fraction of the HT humin, but the HA ages from the 


\section{Low-Temperature \& Stepped-Combustion of Terrace Sediments}

Table $1{ }^{14} \mathrm{C}$ measurement of 2 sizes $(<64 \mu \mathrm{m}$ and $150-1410 \mu \mathrm{m}$ ) and 3 fractions (HA: humic acid, LT: low temperature, $\sim 400{ }^{\circ} \mathrm{C}$, HT: high temperature, $\sim 1100{ }^{\circ} \mathrm{C}$ ) of all sediment samples from Nanfu terrace. ${ }^{\mathrm{a}}$

\begin{tabular}{|c|c|c|c|c|c|c|}
\hline $\begin{array}{l}\text { AA- } \\
n r\end{array}$ & Lab nr & Sample ID & $\begin{array}{l}\delta^{13} \mathrm{C} \\
(\%)\end{array}$ & $\mathrm{F}$ & ${ }^{14} \mathrm{C}$ age $\mathrm{BP}$ & $\begin{array}{l}\text { \% total } \\
\text { carbon }\end{array}$ \\
\hline 83222 & X12960A & Nanfu $1 \mathrm{E}<63 \mu \mathrm{m} 300^{\circ} \mathrm{C}$ & -19.5 & $0.6562 \pm 0.0085$ & $3380 \pm 100$ & 33 \\
\hline 83222 & X12960B & Nanfu $1 \mathrm{E}<63 \mu \mathrm{m} 350^{\circ} \mathrm{C}$ & -22.5 & $0.6674 \pm 0.0086$ & $3250 \pm 100$ & 59 \\
\hline 83222 & $\mathrm{X} 12960 \mathrm{C}$ & Nanfu $1 \mathrm{E}<63 \mu \mathrm{m} 400^{\circ} \mathrm{C}$ & -21.9 & $0.6258 \pm 0.0094$ & $3760 \pm 120$ & 70 \\
\hline 83222 & X12960D & Nanfu $1 \mathrm{E}<63 \mu \mathrm{m} 450{ }^{\circ} \mathrm{C}$ & -22.1 & $0.5971 \pm 0.0079$ & $4140 \pm 110$ & 81 \\
\hline 83222 & $\mathrm{X} 12960 \mathrm{E}$ & Nanfu $1 \mathrm{E}<63 \mu \mathrm{m} 500^{\circ} \mathrm{C}$ & -25.7 & $0.5580 \pm 0.0093$ & $4690 \pm 130$ & 90 \\
\hline 83222 & $\mathrm{X} 12960 \mathrm{~F}$ & Nanfu $1 \mathrm{E}<63 \mu \mathrm{m} 550{ }^{\circ} \mathrm{C}$ & -23.6 & $0.4990 \pm 0.0015$ & $5590 \pm 240$ & 95 \\
\hline 83222 & X12960G & Nanfu $1 \mathrm{E}<63 \mu \mathrm{m} 600^{\circ} \mathrm{C}$ & $\mathrm{x}$ & & & \\
\hline 83222 & $\mathrm{X} 12960 \mathrm{H}$ & Nanfu $1 \mathrm{E}<63 \mu \mathrm{m} 650^{\circ} \mathrm{C}$ & -21.4 & & & \\
\hline 83222 & X12960I & Nanfu $1 \mathrm{E}<63 \mu \mathrm{m} 700{ }^{\circ} \mathrm{C}$ & -20.5 & & & \\
\hline 83222 & X12960J & Nanfu $1 \mathrm{E}<63 \mu \mathrm{m} 750{ }^{\circ} \mathrm{C}$ & -20.1 & & & \\
\hline 83222 & X12960K & Nanfu $1 \mathrm{E}<63 \mu \mathrm{m} 800^{\circ} \mathrm{C}$ & -21.4 & & & \\
\hline \multirow[t]{2}{*}{83222} & $\mathrm{X} 12960 \mathrm{~L}$ & Nanfu $1 \mathrm{E}<63 \mu \mathrm{m} 1100^{\circ} \mathrm{C}$ & -20.9 & $0.4960 \pm 0.0092$ & $5630 \pm 150$ & 100 \\
\hline & & & & & & cal BP $(1 \sigma)$ \\
\hline 83222 & $\mathrm{X} 12197 \mathrm{H}$ & Nanfu $1 \mathrm{E}<63 \mu \mathrm{m}$ humic acid & -21.6 & $0.7093 \pm 0.0056$ & $2759 \pm 63$ & $2781-2924$ \\
\hline 83222 & $\mathrm{X} 12197 \mathrm{Ht}$ & Nanfu $1 \mathrm{E}<63 \mu \mathrm{m} 11$ & -24.3 & $7 \pm 0.0085$ & $7290 \pm 170$ & 796 \\
\hline 83222 & X12197Lt & Nanfu $1 \mathrm{E}<63 \mu \mathrm{m} 400^{\circ} \mathrm{C}$ & -23.9 & $0.7182 \pm 0.0044$ & $2659 \pm 50$ & 2741 \\
\hline 83223 & X12198H & Nanfu $2 \mathrm{E}<63 \mu \mathrm{m}$ humic acid & -22.1 & $0.6530 \pm 0.0034$ & $3424 \pm 41$ & 3813 \\
\hline 83223 & X12198Ht & Nanfu $2 \mathrm{E}<63 \mu \mathrm{m} 1100^{\circ} \mathrm{C}$ & -23.0 & $0.4966 \pm 0.0085$ & $5620 \pm 140$ & $6285-6600$ \\
\hline 83223 & X12198Lt & Nanfu $2 \mathrm{E}<63 \mu \mathrm{m} 400^{\circ} \mathrm{C}$ & -25.3 & $0.6347 \pm 0.0040$ & $3652 \pm 51$ & $3898-4079$ \\
\hline 83224 & $\mathrm{X} 12199 \mathrm{H}$ & $\begin{array}{l}\text { Nanfu } 2.1 \mathrm{E}<63 \mu \mathrm{m} \text { humic } \\
\text { acid }\end{array}$ & -21.1 & $0.7839 \pm 0.0087$ & $1955 \pm 89$ & 1743-2037 \\
\hline 83224 & X12199Ht & Nanfu $2.1 \mathrm{E}<63 \mu \mathrm{m} 1100{ }^{\circ} \mathrm{C}$ & -23.2 & $0.3779 \pm 0.0081$ & $7820 \pm 170$ & $8428-8970$ \\
\hline 83224 & X12199Lt & Nanfu $2.1 \mathrm{E}<63 \mu \mathrm{m} 400{ }^{\circ} \mathrm{C}$ & -23.5 & $0.6927 \pm$ & 29 & 30 \\
\hline 83225 & $\mathrm{X} 12200 \mathrm{H}$ & Nanfu $1 \mathrm{~W}<63 \mu \mathrm{m}$ humic acid & -21.6 & $0.7540 \pm 0.0045$ & & 21 \\
\hline 83225 & $\mathrm{X} 12200 \mathrm{Ht}$ & Nanfu $1 \mathrm{~W}<63 \mu \mathrm{m} 1100{ }^{\circ} \mathrm{C}$ & -22.7 & $0 \pm 0.0064$ & 120 & \\
\hline 83225 & X12200Lt & $00^{\circ} \mathrm{C}$ & -22.8 & & & \\
\hline 83226 & $\mathrm{X} 12201 \mathrm{H}$ & nic acid & -21.3 & & & \\
\hline 83226 & $\mathrm{X} 12201 \mathrm{Ht}$ & $00{ }^{\circ} \mathrm{C}$ & -22.0 & 120 & 120 & 775 \\
\hline 83226 & X12201Lt & Nanfu $2 \mathrm{~W}<63 \mu \mathrm{m} 400{ }^{\circ} \mathrm{C}$ & -23.1 & $0.6668 \pm 0.0086$ & $3260 \pm 100$ & -3610 \\
\hline 83229 & $\mathrm{X} 12204 \mathrm{H}$ & $\begin{array}{l}\text { Nanfu } 2.1 \mathrm{E}>150<1410 \mu \mathrm{m} \\
\text { humic acid }\end{array}$ & -21.7 & $0.7892 \pm 0.0050$ & $1902 \pm 50$ & $1741-1922$ \\
\hline 83229 & $\mathrm{X} 12204 \mathrm{Ht}$ & $\begin{array}{l}\text { Nanfu } 2.1 \mathrm{E}>150<1410 \mu \mathrm{m} \\
1100^{\circ} \mathrm{C}\end{array}$ & -20.3 & $\mathrm{x}$ & $\mathrm{x}$ & \\
\hline 83229 & $\mathrm{X} 12204 \mathrm{Lt}$ & $\begin{array}{l}\text { Nanfu } 2.1 \mathrm{E}>150<1410 \mu \mathrm{m} \\
400^{\circ} \mathrm{C}\end{array}$ & -23.8 & $0.8891 \pm 0.0074$ & $4670 \pm 110$ & $5300-5582$ \\
\hline 83230 & $\mathrm{X} 12205 \mathrm{H}$ & $\begin{array}{l}\text { Nanfu } 1 \mathrm{~W}>150<1410 \mu \mathrm{m} \text { hu- } \\
\text { mic acid }\end{array}$ & -22.0 & $0.7334 \pm 0.0036$ & $2490 \pm 39$ & 2490-2712 \\
\hline 83230 & $\mathrm{X} 12205 \mathrm{Ht}$ & $\begin{array}{l}\text { Nanfu } 1 \mathrm{~W}>150<1410 \mu \mathrm{m} \\
1100^{\circ} \mathrm{C}\end{array}$ & -23.0 & $0.2520 \pm 0.0100$ & $11,080 \pm 330$ & $12,652-13,267$ \\
\hline 83230 & $\mathrm{X} 12205 \mathrm{Lt}$ & $\begin{array}{l}\text { Nanfu } 1 \mathrm{~W}>150<1410 \mu \mathrm{m} \\
400^{\circ} \mathrm{C}\end{array}$ & -23.8 & $0.5591 \pm 0.0074$ & $4670 \pm 110$ & $5300-5582$ \\
\hline 83231 & $\mathrm{X} 12206 \mathrm{H}$ & $\begin{array}{l}\text { Nanfu } 2 \mathrm{~W}>150<1410 \mu \mathrm{m} \text { hu- } \\
\text { mic acid }\end{array}$ & -22.2 & $0.7370 \pm 0.0047$ & $2451 \pm 51$ & 2363-2697 \\
\hline 83231 & $\mathrm{X} 12206 \mathrm{Ht}$ & $\begin{array}{l}\text { Nanfu } 2 \mathrm{~W}>150<1410 \mu \mathrm{m} \\
1100{ }^{\circ} \mathrm{C}\end{array}$ & -21.4 & $0.3020 \pm 0.0260$ & $9620 \pm 690$ & $10,160-12,086$ \\
\hline 83231 & X12206Lt & $\begin{array}{l}\text { Nanfu } 2 \mathrm{~W}>150<1410 \mu \mathrm{m} \\
400^{\circ} \mathrm{C}\end{array}$ & -23.4 & $0.6181 \pm 0.0093$ & $3860 \pm 120$ & $4090-4425$ \\
\hline 83222 & X12960I & Nanfu $1 \mathrm{E}<63$ um $700{ }^{\circ} \mathrm{C}$ & -20.5 & & & \\
\hline 83222 & X12960J & Nanfu $1 \mathrm{E}<63$ um $750{ }^{\circ} \mathrm{C}$ & -20.1 & & & \\
\hline 83222 & $\mathrm{X} 12960 \mathrm{~K}$ & Nanfu $1 \mathrm{E}<63$ um $800^{\circ} \mathrm{C}$ & -21.4 & & & \\
\hline 83222 & X12960L & Nanfu $1 \mathrm{E}<63$ um $1100^{\circ} \mathrm{C}$ & -20.9 & $0.4960 \pm 0.0092$ & $5630 \pm 150$ & 100 \\
\hline
\end{tabular}

${ }^{\mathrm{a}} \mathrm{X}$ : not enough carbon to be measured. 


\section{S-L Wang et al.}
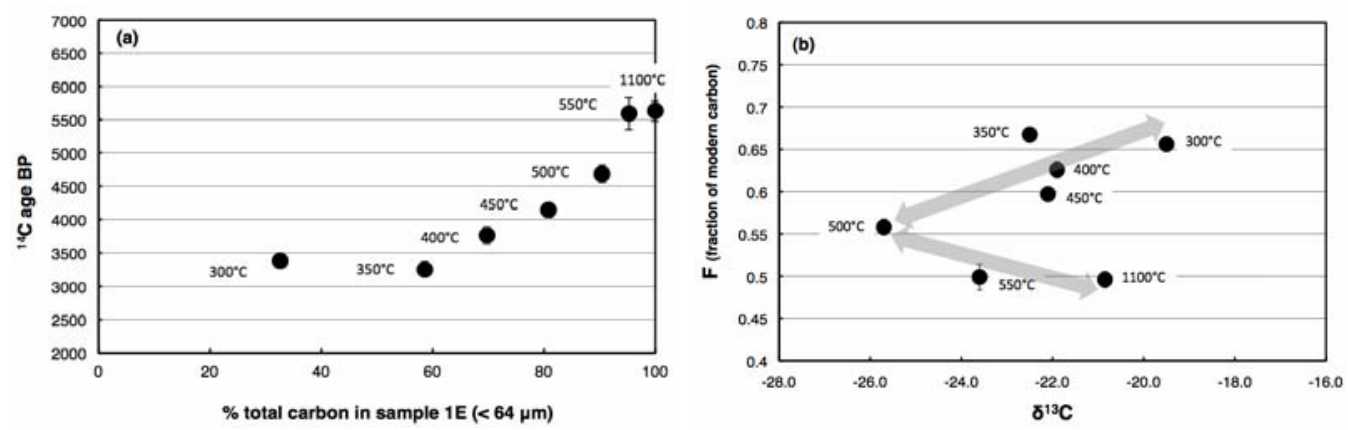

Figure 2 Temperature stepped-combustion results from the sieved fine sediment sample, 1E, on Nanfu terrace. a) Percent total carbon liberated versus ${ }^{14} \mathrm{C}$ age. "\% total carbon" is the total carbon after AAA pretreatment. Combustion temperature is marked at the site of the ${ }^{14} \mathrm{C}$ data and error bars are smaller than the markers. b) $\delta^{13} \mathrm{C}$ versus fraction modern carbon (F). Arrows imply fractions are mixed from LT end-member $\left(\sim 300^{\circ} \mathrm{C}\right)$, intermediate end-member $\left(\sim 500^{\circ} \mathrm{C}\right)$, and $\mathrm{HT}$ endmember $\left(\sim 1100^{\circ} \mathrm{C}\right)$.

coarse fraction are indistinguishable from the fine fraction; 4) the HT fraction is always older than the other humin fractions; and 5) the HT ages are more variable than the LT or HA ages.

By comparing the $\delta^{13} \mathrm{C}$ values in Figure 4, we see that the ${ }^{14} \mathrm{C}$ and $\delta^{13} \mathrm{C}$ compositions of HA from both the fine and coarse grains fall within a small range, while the $\delta^{13} \mathrm{C}$ of the LT samples show relatively lighter isotopic compositions that are distinct from the HA values. The carbon sources in the HA and LT fractions are thus different in terms of $\delta^{13} \mathrm{C}$. The HT results have scattered $\delta^{13} \mathrm{C}$ values, but the values overlap with both the LT and HA ranges. The scatter in the results from the HT fraction are not surprising as they include all of the carbon that is released $>450{ }^{\circ} \mathrm{C}$, up to $1100{ }^{\circ} \mathrm{C}$.

\section{DISCUSSION}

From the incremental stepped-combustion experiment, we have found that more than $60 \%$ of the total carbon in the fine-grain fraction is released during the LT combustion (Figure 2a). We expect that this carbon is primarily associated with clay minerals in the sample as the sediments are largely composed of clay. Detailed X-ray diffraction (XRD) analyses show that the clay minerals in the fine fraction of the Nanfu sediments are a combination of chlorite and illite (unpublished data). Burr et al. (2009) performed stepped-combustion experiments on several pure clays and found that most of the carbon in chlorite and illite will oxidize at temperatures below $450{ }^{\circ} \mathrm{C}$. Other clay minerals, such as kaolinite, require higher temperatures to release $60 \%$ of their carbon. These results are consistent with the idea that organic carbon is stabilized by clay minerals, and protected from biodegradation (Six et al. 2002; Eusterhues et al. 2003; Wattel-Koekkoek et al. 2003).

Our results are consistent with previous stepped-combustion studies of very fine-grained sediments $\left(<64 \mu \mathrm{m}\right.$ ) that concluded that the humin fraction is heterogeneous with respect to ${ }^{14} \mathrm{C}$ (McGeehin et al. 2001) and that the AAA pretreatment cannot discriminate between them (Head and Zhou 2000). The ages of the 300 and $350{ }^{\circ} \mathrm{C}$ fractions of the $50{ }^{\circ} \mathrm{C}$ stepped-combustion experiment described here are in good agreement, supporting the idea that the LT carbon is relatively homogeneous and represents an end-member in terms of ${ }^{14} \mathrm{C}$ content (Figure 2a). The age of the $400{ }^{\circ} \mathrm{C}$ fraction is slightly older, and from 400 to $500{ }^{\circ} \mathrm{C}$ the ages of the combustion products become progressively older. There is very little carbon in the higher-temperature combustion products, above $550^{\circ} \mathrm{C}$, and we were not able to make ${ }^{14} \mathrm{C}$ measurements on all of these splits (Figure 2a). However, the ${ }^{14} \mathrm{C}$ ages at 550 and $1100{ }^{\circ} \mathrm{C}$ are consistent with one another (Figure 2a), suggesting a common ${ }^{14} \mathrm{C}$ compo- 


\section{Low-Temperature \& Stepped-Combustion of Terrace Sediments}

nent. The $50{ }^{\circ} \mathrm{C}$ stepped-combustion results show clearly the inherently heterogeneous nature of the HT fraction, which captures all of the carbon liberated by combustion between 400 and $550{ }^{\circ} \mathrm{C}$, and up to $1100^{\circ} \mathrm{C}$. From consideration of the relationships apparent in Figure 2a, a logical step to follow this study would be to re-run the samples to capture the $>550{ }^{\circ} \mathrm{C}$ fraction separately from the 400 to $500{ }^{\circ} \mathrm{C}$ fraction, in order to better characterize the ${ }^{14} \mathrm{C}$ content of the HT end-member.

From the $\delta^{13} \mathrm{C}$ values in Figure $2 \mathrm{~b}$, we can see that the carbon in the $500{ }^{\circ} \mathrm{C}$ fraction has the most depleted $\delta^{13} \mathrm{C}$ content of any of the temperature fractions. That is, it represents a third end-member, which cannot be identified with ${ }^{14} \mathrm{C}$ data alone (as in Figure 2a). This third component is not seen in pure clays, where $\delta^{13} \mathrm{C}$ and ${ }^{14} \mathrm{C}$ have been observed to follow a single trajectory when plotted together (Burr et al. 2009).

Our study of the coarse fraction $(150-1410 \mu \mathrm{m})$ shows the same general trends as the fine-grained fraction, with more scatter and a larger spread of ages between the HA, LT, and HT fractions (Figures 3 and 4). This result could explain some of the variability described by Brock et al. (2010), who used stepped-combustion on bulk sediments, without sieving.

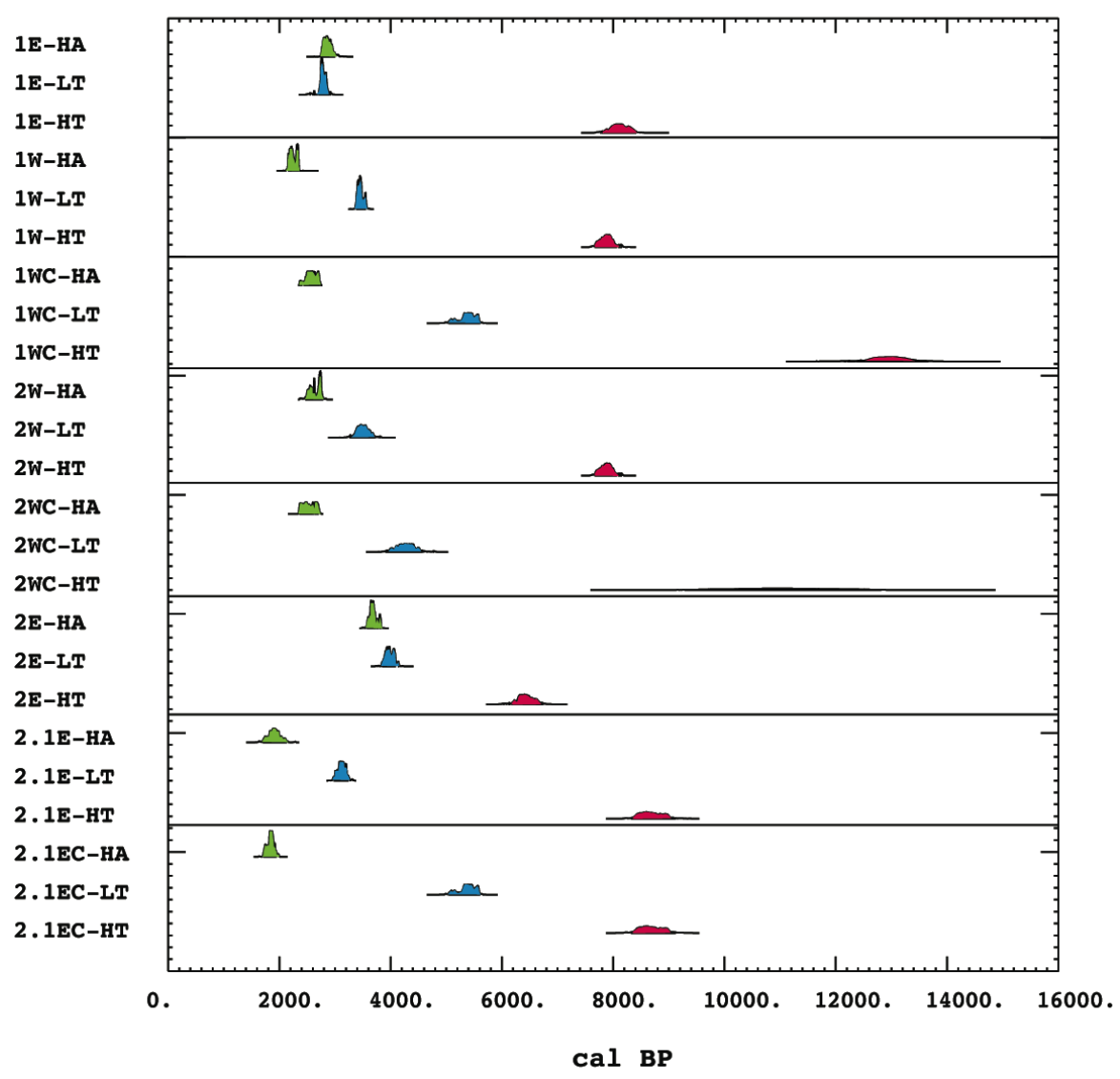

Figure 3 Calibrated ${ }^{14} \mathrm{C}$ ages of sieved sediment samples (fine grains without suffix, coarse grains with suffix “C”) and 3 fractions, HA, LT, and HT, of each sample. HA: humic acid with green color filled; LT: low temperature, $\sim 400{ }^{\circ} \mathrm{C}$, combustion of humin in blue; HT: high temperature, $\sim 1100{ }^{\circ} \mathrm{C}$, combustion of humin in red. ${ }^{14} \mathrm{C}$ ages are calibrated to cal yr BP via CALIB v 6.10 (Stuiver et al. 2005). 


\section{S-L Wang et al.}

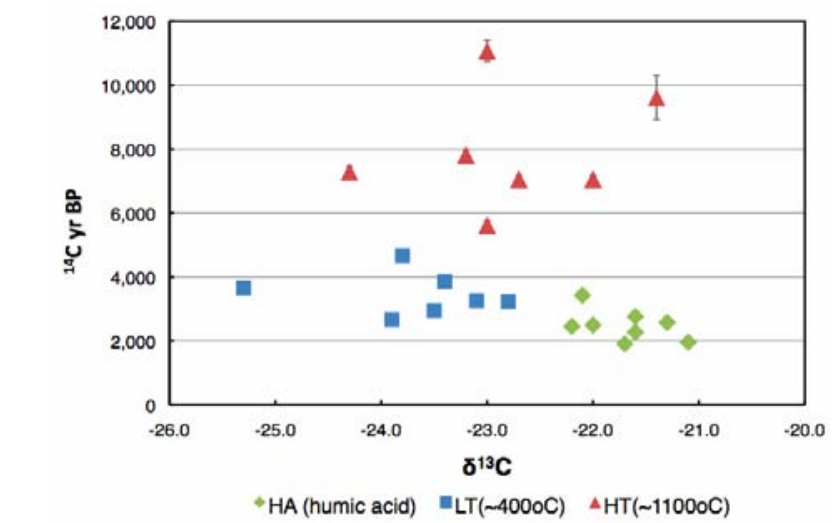

Figure 4 Plot of $\delta^{13} \mathrm{C}$ versus ${ }^{14} \mathrm{C}$ ages of 3 fractions, HA, HT, and LT, of all fine and coarse sediment samples. Patterns are the same as those in Figure 3.

In order to place realistic age constraints on the Nanfu terrace site, we used the weighted average isotopic composition measured in the HA, LT, and HT splits for the $<64-\mu \mathrm{m}$ fraction (Table 2, complete data in Table 1). Level 1 (collected in sand/silt layer) and level 2 (collected in cobble layer) samples are averaged together. As reflected in the uncertainties in Table 2, the internal agreement of level 1 and level 2 in the result shows that these sediments of sand and cobble layers were deposited during a short period of time, which implies a rapid deposition rate. This data shows that the sediments formed at least from 7000 to about $3000{ }^{14} \mathrm{C}$ yr BP. Various residence times of organic carbon associated with clay minerals that liberate carbon at different temperature are dated here. The age of $7000 \mathrm{yr}$ is a minimum age of the deposit because we know that the HT fraction contains a large proportion of organic carbon released between 400 and $550{ }^{\circ} \mathrm{C}$, which yields younger ages. Our HA ages are consistently younger than the LT and HT ages. This is different from the results obtained on alluvial sediments from the Dominican Republic, with LT ages that are older than HT and HA ages (McGeehin et al. 2001). Our samples are also different from buried soils in Colorado, USA, which have HA ages that are older than LT and HT ages (Mayer et al. 2008).

Table 2 Weighted averages of $\delta^{13} \mathrm{C}$ and ${ }^{14} \mathrm{C}$ results for all HA samples, and the LT and HT fractions for $<64-\mu \mathrm{m}$ grain size fraction. Levels 1 and 2 are averaged together.

\begin{tabular}{lccc}
\hline & HA (8 samples) & LT (5 samples) & HT (5 samples) \\
\hline$\delta^{13} \mathrm{C}$ (\%) & $-21.7 \pm 0.4$ & $-23.7 \pm 0.4$ & $-23.0 \pm 0.4$ \\
${ }^{14} \mathrm{C}$ age (yr BP) & $2460 \pm 470$ & $3130 \pm 170$ & $7060 \pm 430$ \\
\hline
\end{tabular}

Our oldest ${ }^{14} \mathrm{C}$ date is about $11{ }^{14} \mathrm{C}$ kyr $\mathrm{BP}$, which is about $13 \mathrm{kyr}$ cal $\mathrm{BP}$, coming from the coarse grain fraction (Table 1). This is broadly consistent with the $>20 \mathrm{kyr}$ cal BP date for the uplift of the formation of the terrace, according to OSL data (Chen 2006). The OSL dates may be expected to correspond to the time of uplift while the ${ }^{14} \mathrm{C}$ ages should reflect an interval of soil development, prior to burial. The climate became warmer and wetter during the Holocene and reached a maximum between 4000-6000 yr ago, and the highest sea level at Taiwan Strait was 4700 yr ago among the range (Chen and Liu 1996). A pollen study in the mountains of Taiwan also recorded the maximum warm weather between 5300 and $4800 \mathrm{yr}$ ago (Liew et al. 1994). This pollen record also reflected a cooler period between 3700 and 2000 yr ago and after that a warm, wet period with relatively high erosion (Liew et al. 1994). The warm temperature in this period could have promoted vigorous vegetation and soil development on Nanfu terrace. 


\section{Low-Temperature \& Stepped-Combustion of Terrace Sediments}

Our method of extracting clay from bulk sediment allows for the identification of 3 components in humin according to their ${ }^{14} \mathrm{C}$ and $\delta^{13} \mathrm{C}$ contents. From the close association of carbon and clay, we expect that the particular clay minerals present will determine the temperature relationships observed during the stepped-combustion experiments. The next step in refining this approach will be to study the age relationships from stepped-combustion experiments performed on pure clay minerals, of the type that occur in terrace sediments in Taiwan. This method could provide useful age control for soil development on river terraces across Taiwan, where very few charcoals are available and partial bleaching issues limit the OSL technique. These ages might not only reflect climate change, but also imply the age of forming terraces and their association with tectonic activity along faults in Taiwan.

\section{CONCLUSION}

In Nanfu sediments, more than $60 \%$ of the total carbon was oxidized at temperatures below $400{ }^{\circ} \mathrm{C}$, as observed from the stepped-combustion in $50^{\circ} \mathrm{C}$ increments. LT results produce younger ages and HT results are older. This result verifies at least 2 end-members of carbon sources bound in clay minerals in terms of ${ }^{14} \mathrm{C}$, and we expect that the temperature at which carbon is oxidized is related to the clay minerals in the sample. A potential third end-member $\left(\sim 500^{\circ} \mathrm{C}\right)$ has been identified with a combination of $\delta^{13} \mathrm{C}$ and ${ }^{14} \mathrm{C}$ values in this study. The HT fraction $\left(>400{ }^{\circ} \mathrm{C}\right)$ as measured in previous studies is likely to be isotopically heterogeneous and should be measured on carbon oxidized higher than $550^{\circ} \mathrm{C}$. It is important to sieve the sediments prior to combustion, as seen in the differences between the $<64-\mu \mathrm{m}$ and 150 - to $1410-\mu \mathrm{m}$ fractions here. It is always difficult to find charcoals and obtain absolute ages on terraces in Taiwan. However, based on the result of consistently increasing ${ }^{14} \mathrm{C}$ ages of HA, LT, and HT, we can make our best age estimate by pooling together all of the data and using the variance as an estimate of the uncertainty. These 3 time plots of HA, LT, and HT may record 3 periods of soil development in warm and wet climate in Holocene, while OSL results give us the possible uplift time of Nanfu terrace back to Pleistocene and the high-temperature ${ }^{14} \mathrm{C}$ component can represent the minimum age of uplift.

\section{ACKNOWLEDGMENTS}

We thank Ling-Ho Chung and Yu-Ting Kuo for their assistance in fieldwork, and Dr Chi-Yu Lee for XRD measurement in Taiwan. We thank Dr Brad Rosenheim for a thorough review, which assisted us in improving the manuscript. We also thank the staff and students at the NSF-Arizona AMS Facility for their kindly guidance and assistance in making the AMS ${ }^{14} \mathrm{C}$ measurements. We have benefited from discussions with Nina YN Lin in California Institute of Technology. Our project was supported in part by the Central Geological Survey (5226902000-02-95-01) and by National Taiwan University. Funding from the National Science Foundation (EAR0929458) also supported this effort.

\section{REFERENCES}

Anderson DW, Paul EA. 1984. Organo-mineral complexes and their study by radiocarbon dating. Soil Science Society of America Journal 48(2):298-301.

Balesdent J, Besnard E, Arrouays D, Chenu C. 1998. The dynamics of carbon in particle-size fractions of soil in a forest-cultivation sequence. Plant and Soil 201(1): 49-57.

Brock F, Froese DG, Roberts RG. 2010. Low temperature (LT) combustion of sediments does not necessarily provide accurate radiocarbon ages for site chronology. Quaternary Geochronology 5(6):625-30.

Burr GS, McGeehin J, Chen YG, Mayer J, Leonard A, Cheng L, Jull AJT. 2009. Radiocarbon in clay minerals: a stepped-combustion approach. Abstract P-109. 20th International Radiocarbon Conference. 31 May5 June 2009. Kona, Hawaii.

Chen WS, editor. 2006. Trenching and Paleoseismology Research and OSL Dating. Central Geological Sur- 


\section{S-L Wang et al.}

vey, Taipei Report 95-08-1. 146 p. In Chinese.

Chen YG, Liu TK. 1996. Sea level changes in the last several thousand years, Penghu Islands, Taiwan Strait. Quaternary Research 45(3):254-62.

Eusterhues K, Rumpel C, Kleber M, Kögel-Knabner I. 2003. Stabilization of soil organic matter by interactions with minerals as revealed by mineral dissolution and oxidative degradation. Organic Geochemistry 34(12):1591-600.

Head MJ, Zhou WJ. 2000. Evaluation of $\mathrm{NaOH}$ leaching techniques to extract humic acids from palaeosols. Nuclear Instruments and Methods in Physics Research B 172(1-4):434-9.

Liew PM, Huang SY. 1994. A 5000-year pollen record from Chitsai lake, central Taiwan. Terrestrial, Atmospheric and Oceanic Sciences 5(3):411-9.

Martin CW, Johnson WC. 1995. Variation in radiocarbon ages of soil organic matter fractions from late Quaternary buried soils. Quaternary Research 43(2):232-7.

Mayer JH, Burr GS, Holliday VT. 2008. Comparisons and interpretations of charcoal and organic matter radiocarbon ages from buried soils in north-central Colorado, USA. Radiocarbon 50(3):331-46.

McGeehin J, Burr GS, Jull AJT, Reines D, Gosse J, Davis PT, Muhs D, Southon JR. 2001. Stepped-combustion ${ }^{14} \mathrm{C}$ dating of sediment: a comparison with established techniques. Radiocarbon 43(2A):255-61.

McGeehin J, Burr GS, Hodgins G, Bennett SJ, Robbins JA, Morehead N, Markewich H. 2004. Stepped combustion ${ }^{14} \mathrm{C}$ dating of bomb carbon in lake sediment. Radiocarbon 46(2):893-900.

Ota Y, Lin YNN, Chen YG, Matsuta N, Watanuki T, Chen YW. 2009. Touhuanping Fault, an active wrench fault within fold-and-thrust belt in northwestern Taiwan, documented by spatial analysis of fluvial terraces. Tectonophysics 474(3-4):559-70.

Schöning I, Kögel-Knabner I. 2006. Chemical composition of young and old carbon pools throughout Cambisol and Luvisol profiles under forests. Soil Biology and Biochemistry 38(8):2411-24.

Schöning I, Morgenroth G, Kögel-Knabner I. 2005. O/Nalkyl and alkyl C are stabilized in fine size fractions of forest soils. Biogeochemistry 73(3):475-97.

Shyu JBH, Sieh K, Chen YG, Liu CS. 2005. Neotectonic architecture of Taiwan and its implications for future large earthquakes. Journal of Geophysical Research 110: B08402, doi:10.1029/2004JB003251.

Six J, Conant RT, Paul EA, Paustian K. 2002. Stabilization mechanisms of soil organic matter: implications for C-saturation of soils. Plant and Soil 241:155-76.

Sollins P, Swanston C, Kleber M, Filley T, Kramer M, Crow S, Caldwell BA, Lajtha K, Bowden R. 2006. Organic $\mathrm{C}$ and $\mathrm{N}$ stabilization in a forest soil: evidence from sequential density fractionation. Soil Biology and Biochemistry 38(11):3313-24.

Stuiver M, Reimer PJ, Reimer RW. 2005. CALIB 5.0. [WWW program and documentation]. http:// calib.qub.ac.uk/calib/.

Suppe J, Namson J. 1979. Fault-bend origin of frontal folds of the western Taiwan fold-and-thrust belt. $P e$ troleum Geology of Taiwan 16:1-18.

Sutton R, Sposito G. 2005. Molecular structure in soil humic substances: the new view. Environmental Science \& Technology 39(23):9009-15.

Torn MS, Trumbore SE, Chadwick OA, Vitousek PM, Hendricks DM. 1997. Mineral control of soil organic carbon storage and turnover. Nature 389(6647):170-

Trumbore SE, Chadwick OA, Amundson R. 1996. Rapid exchange between soil carbon and atmospheric carbon dioxide driven by temperature change. Science 272(5260):393-6.

Wattel-Koekkoek EJW, Ruurman P, van der Plicht J, Wattel E, van Breemen N. 2003. Mean residence time of soil organic matter associated with kaolinite and smectite. European Journal of Soil Science 54(2): 269-78.

Xu S, Hoshizumi H, Ochiai Y, Aoki H, Uto K. $2004 .{ }^{14} \mathrm{C}$ dating of soil samples from the Unzen Volcano scientific drilling boreholes. Nuclear Instruments and Methods in Physics Research B 223-224:560-7.

Yu S-B, Chen HY, Kuo LC. 1997. Velocity field of GPS stations in the Taiwan area. Tectonophysics 274(1-3): 41-59. 